\title{
"Ownership structure and corporate performance: evidence from property and real estate public companies in Indonesia"
}

\begin{tabular}{|c|c|}
\hline AUTHORS & $\begin{array}{l}\text { Mustaruddin Saleh } \\
\text { Giriati Zahirdin } \\
\text { Ellen Octaviani }\end{array}$ \\
\hline ARTICLE INFO & $\begin{array}{l}\text { Mustaruddin Saleh, Giriati Zahirdin and Ellen Octaviani (2017). Ownership } \\
\text { structure and corporate performance: evidence from property and real estate } \\
\text { public companies in Indonesia. Investment Management and Financial } \\
\text { Innovations, } 14(2-1), 252-263 \text {. doi:10.21511/imfi.14(2-1).2017.10 }\end{array}$ \\
\hline DOI & http://dx.doi.org/10.21511/imfi.14(2-1).2017.10 \\
\hline RELEASED ON & Thursday, 27 July 2017 \\
\hline RECEIVED ON & Friday, 14 April 2017 \\
\hline \multirow[t]{2}{*}{ ACCEPTED ON } & Tuesday, 06 June 2017 \\
\hline & \begin{tabular}{|l|}
$(c))$ EY \\
\end{tabular} \\
\hline LICENSE & $\begin{array}{l}\text { This work is licensed under a Creative Commons Attribution } 4.0 \text { International } \\
\text { License }\end{array}$ \\
\hline JOURNAL & "Investment Management and Financial Innovations" \\
\hline ISSN PRINT & $1810-4967$ \\
\hline ISSN ONLINE & $1812-9358$ \\
\hline PUBLISHER & LLC "Consulting Publishing Company "Business Perspectives" \\
\hline FOUNDER & LLC "Consulting Publishing Company "Business Perspectives" \\
\hline
\end{tabular}

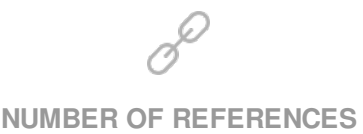

37

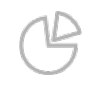

NUMBER OF FIGURES

0

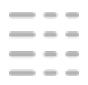

NUMBER OF TABLES

2

(C) The author(s) 2022. This publication is an open access article. 


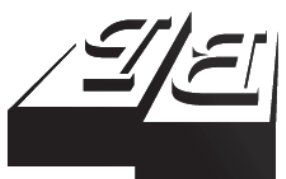

BUSINESS PERSPECTIVES

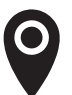

LLC "CPC "Business Perspectives" Hryhorii Skovoroda lane, 10, Sumy, 40022, Ukraine

www.businessperspectives.org

Received on: $14^{\text {th }}$ of April, 2017 Accepted on: $6^{\text {th }}$ of June, 2017

(C) Mustaruddin Saleh, Giriati

Zahirdin, Ellen Octaviani, 2017

Mustaruddin Saleh, Dr., Faculty of Economics and Business (FEB),

Universitas Tanjungpura, Pontianak, Indonesia.

Giriati Zahirdin, Faculty of Economics and Business (FEB), Universitas Tanjungpura, Pontianak, Indonesia.

Ellen Octaviani, Paramount Reuben Extra Prep. Pty Limited, Sydney, Australia.

\section{(ㄷ)(i)}

This is an Open Access article, distributed under the terms of the Creative Commons Attribution 4.0 International license, which permits unrestricted re-use, distribution, and reproduction in any medium, provided the original work is properly cited.
Mustaruddin Saleh (Indonesia), Giriati Zahirdin (Indonesia), Ellen Octaviani (Indonesia)

\section{OWNERSHIP STRUCTURE} AND CORPORATE PERFORMANCE: EVIDENCE FROM PROPERTY AND REAL ESTATE PUBLIC COMPANIES IN INDONESIA

\begin{abstract}
This paper has proposed a specific case in the property and real estate sector regarding the impact of ownership structure and corporate performance, since this sector is one of those with booming investment in Indonesia. The ownership structure was represented by the institutional investor and managerial ownership, and the Economic Value Added (EVA) and Tobin's Q were used as a proxy for firm performance. This study utilized the purposive sampling of 240 observations over the period 2010-2015. The fixed and random effect panel data model was employed to determine the relationship among the variables. Findings show that the institutional investor and company's size, as well as debt ratio, are important in explaining firm performance, while managerial ownership has a partially significant effect on the performance of companies in this industry.
\end{abstract}

\section{Keywords}

\section{JEL Classification} Economic Value Added (EVA), Tobin's Q

\section{INTRODUCTION}

Corporate governance refers to the framework of mechanisms and practices by which corporations are controlled and directed. It refers to the company's relationship with all its stakeholders. The application of good corporate governance can help a company in optimizing the allocation of resources, so as to experience a significant growth. The significant growth of the company maximizes the shareholder's wealth and it can improve the shareholder's credibility towards the company. Thus, the application of good corporate governance in all aspects of the company is a requirement to become a solid and leading company. Good corporate governance can be achieved whenever there is a good corporate policy in organizing the company's ownership structure. Although there is a separation between ownership and management, there is also a tendency for the founder to act as the commissioner or management board. It can trigger agency problem (conflict) between the owners and managers or the majority and minority shareholders. Besides, a previous study has shown that agency conflict could arise from the separation of the ownership and management (Jensen \& Meckling, 1976). 
Agency problem was discussed in the agency theory. The agency theory is a set of ideas on organizational control, based on the belief that the separation of the ownership from management creates the potential for the wishes of owners to be ignored (Pearce \& Richard, 2011, p. 35). There are two main components of agency theory, which are principals (owners or shareholders) and agents (managers). The separation of control from ownership implies that professional managers govern a firm on behalf of the firm's owners, which means that managers have the obligation of maximizing the shareholder's welfare; on the other hand, managers also have the intention of maximizing their own welfare. The differences in interest can lead to conflicts, because the managers can take decisions contrary to that of the owners.

The relationship between the ownership structure and company performance was previously discussed by researchers such as Smith (1990), Leng (2004), Demsettz and Villalonga (2001), Lichtenberg and Pushner (1994), Craswell et al. (1997), Lemmon and Lins (2003), as well as Kapopoulos and Lazaretou (2007). One of such studies was conducted by Ongore et al. (2011). They analyzed the impact of ownership structure on the firm performance by utilizing 42 listed companies in Kenya. The research showed that ownership concentration and government ownership had a significant negative relationship with firm performance, while foreign, diffuse, corporate and managerial ownership had a significant positive relationship with firm performance. Also, Wahla et al. (2012) examined non-financial listed companies on Karachi Stock Exchange and bound that managerial ownership has a significant negative relationship with firm performance; concentrated ownership showed insignificant relationship with firm performance; leverage had a significant negative relationship with firm performance, and an insignificant relationship with asset turnover and firm performance. In previous studies, the ownership structure's impact on firm performance had different results based on the research findings. The variable used in the previous research was also different, which made the authors consider conducting another research on the influence of ownership structure on company performance with the independent variables: institutional and managerial ownership.

According to Schreiben (2013), property analysts have predicted that in less than 10 years, the property and real estate sector in Indonesia will be a major contributor to the world economy. Based on the data provided by the International Monetary Fund (IMF) and Pramerica Real Estate Investors Research in 2011, the contribution of Indonesia's property and real estate sector was only USD 189.1 billion. But its value is predicted to grow by $200 \%$ in 2021 to USD 563 billion, which can make Indonesia the world's largest contributor to the property and real estate sector, as compared to South Korea, Canada and Japan. The development of the property and real estate sector is currently providing opportunities and chances for stakeholders in business. There are several factors that can affect the development of this sector. First is the political and economic stability in Indonesia. Both sectors are very helpful in creating high foreign investment climate in Indonesia. The second is the rapid growth of population that induces the supply of the property and real estate sector, which is less than the demand from the society. Third, the mortgage interest rate in Indonesia is declining with average $11 \%$ for basic mortgage interest rate, and with inflation rate during $2013-2015$ are $8.38 \%, 8.36 \%$ and $3.35 \%$, respectively. These opportunities attract both domestic and foreign investors to Indonesia and make funds flow into Indonesia through foreign direct investment in orders to improve the performance of the property and real estate sector.

Indonesia has a high rate of urbanization with a significant proportion of young people and will increase demand for housing over the next decade. The World Bank estimates there are about 900,000 new households per year in Indonesia. Data from the Central Bureau of Statistics (BPS) state that the number of backlogs has reached 12 million units in 2013, while the home production supply is around 250,000400,000 per year (World Bank). To catch up with the housing supply, the government is launching a program of building 1 million housing units per year. With this information, it is clear that the housing needs are still very high, thus providing a great opportunity for industry to flourish. Then, the facts show that during the period of 2012 and the first half of 2013, Indonesia's property sector grew rapidly, 
so the profits of Indonesian property developers rised sharply ( 26 out of 45 property companies listed on the Indonesia Stock Exchange in 2012 posted a net profit growth of over 50\%).

According to Schaar (2015), it is worthy to understand why the property sector 'heats up' in this period. First, this strong growth occurs due to the fertile expansion of the Indonesian economy. With GDP growth at + $6 \%$ points (year-on-year), Indonesia's per capita GDP and people's purchasing power strengthen along with it, which implies that more and more Indonesians are able to afford property. Strong middle class consumer spending makes the residential business segment (homes, apartments and condominiums) the largest contributor to Indonesia's property sector accounting for about $60 \%$ of the total property sector.

Second, Indonesia's demographic composition supports economic growth, including the property sector. Indonesia has a large population (approximately 250 million people by 2015), which is becoming more and more prosperous, reflected by Indonesia's fast-growing middle class segment. Each year several million Indonesians are added to this segment. Moreover, the country has a young population of about $50 \%$ of the population under the age of 30, implying that many Indonesians are predicted to buy their first property in the near and medium term.

Third, Indonesia's property market rose sharply due to lower central bank interest rates. Between February 2012 and mid-2013, Indonesia's central bank (BI) kept its benchmark interest rate at 5.75 percent, the lowest policy rate in the nation's history with the largest economy in Southeast Asia. Indonesia's commercial banks are experiencing significant increases in mortgage lending. In May 2013, about 46\% of total bank credits were allocated to consumer mortgage lending.

Furthermore, Schaar (2015) noted the high growth of this sector in the second half of 2013, Bank Indonesia is increasingly concerned about the development of property bubbles as the general economy is slowing, but the property sector is rising very high in the first half of 2013. Bank Indonesia (BI) has detected speculative purchases and thereby it implements monetary tightening policies. Although it is unlikely that the bubble will erupt (because domestic demand for property remains large, and most purchases are made by end users), speculative purchases do grow. Together, these factors led to a decline in the Indonesian property market. A survey from Bank Indonesia shows that residential property sales in the first quarter of 2015 declined significantly in quarter-to-quarter (q/q) comparisons.

Indonesia's economic growth slowed to a six-year low in the first quarter of 2015, so, the authorities are determined to implement measures to boost economic growth. Since the central bank has no room to cut the $\mathrm{BI}$ rate (due to high inflation, wide transaction deficits and severe external pressures), BI decided to raise the lean-to-value (LTV) ratio for home mortgage loans starting from June 2015, thereby reducing the minimum down payment obligation for first home buyers. Then, the Government of Indonesia announces that foreigners will be allowed to own luxury apartments with a minimum value of Rp 5 billion. Interest rates are predicted to remain high for the medium term and a quick rebound from Indonesia's GDP growth is unlikely to happen, but for the medium and long term, the Indonesian property sector remains promising. One reason is because Indonesia's property prices are among the cheapest in Southeast Asia. Moreover, the high demand for property will continue to occur due to the large and young Indonesian population, while urbanization and higher living standards contribute to property demand.

From the background description above, the objectives of the research are to examine the ownership structure's development and company performance; to investigate the influence of institutional ownership on firm performance; and to investigate the influence of managerial ownership firm performance. The remaining part of the study is organized as follows: section 1 provides a literature review of theory and empirical studies related to the current study. Section 2 discusses the methodology employed by the study to achieve its objectives. Section 3 reports and discusses the results of the study. Final section provides the conclusions and recommendations. 


\section{LITERATURE REVIEW}

\subsection{Corporate governance}

Corporate governance is a broad concept used by the company participants to govern the company. Monks and Minow (2001) defined corporate governance as the "relationship among various participants in determining the direction and performance of corporations". They classified the primary participants into 3 groups, which are the shareowners, management and board of directors. The concept of corporate governance was first introduced in 1999 by the Organization for Economic Cooperation and Development (OECD). OECD provided a broader definition of corporate governance in Kirkpatrick (2006):

"Corporate governance involves a set of relationships between a company's management, its board, its shareholders and other stakeholders. Corporate governance also provides the structure through which the objectives of the company are set, and the means of attaining those objectives and monitoring performance are determined. Good corporate performance should provide proper incentives for the board and management to pursue objectives that are in the interests of the company and shareholders and should facilitate effective monitoring".

The above definition is broader and can be simplified as the system by which companies are run and controlled, as well as the manner in which liabilities and rights are shared among the different participants in the organizations. The participants include the board, managers, shareholders and other stakeholders. The definition of corporate governance which is most widely used is "the system by which companies are directed and controlled" (Cadbury Committee, 1992). The corporate governance framework is to encourage the efficient use of company's resources for accountability of the stewardship of these resources. In other perspectives, Oman (2001) defined corporate governance as a term referring to the private and public institutions including laws, regulations and the business practices, which govern the relationship between the corporate managers and the stakeholders. Thus, in the simplest term, corporate governance is on "how investors get the managers to give them back their money" (Shleifer \& Vishny, 1997).

According to the National Committee on Governance (KNKG), there are five principles that must be followed by the company, namely 1) fairness, 2) transparency, 3) independency, 4) accountability and 5) responsibility. It can be concluded that the company that implements good corporate governance can optimize the allocation of resources, protect the equality of stakeholder's interest, maximize the shareholder's wealth and improve the company performance. In addition, the implementation of good corporate governance can also assist the company in solving the conflict of interest that might lead to agency problem.

\subsection{Agency theory}

According to Eisenhardt (1989), the agency theory is concerned with analyzing and resolving problems that occur in the relationship between principals (owners or shareholders) and their agents or top management. Jensen and Meckling (1976) defined the agency relationship as a type of contract in which the principal hires an agent to carry out the services of the firm on his behalf. As mentioned above, it can be simplified that agency relationship consists of two parties, which are the principal (owners) and agent (managers). It occurs when the principals hire the agent to perform the activities on their behalf. In public companies, the agency relationship is reflected by the relationship between the shareholders and the manager. Donaldson and Davis (1991) argue that managers will not act to maximize returns to shareholders unless appropriate governance structures are implemented to safeguard the interests of shareholders. Therefore, the agency theory advocates that the purpose of corporate governance is to minimize the potential for managers to act in a manner contrary to the interests of shareholders.

The conflict between the principal and the agent can be minimized through the application of monitoring mechanism. The emergence of monitoring mechanism or activity makes the agency to incur costs. This is defined as the cost incurred by the principal in order to regulate and monitor 
the manager's performance, whether they work in accordance with the company's objectives or not. Jensen and Meckling (1976) divided the agency costs into three types, which are:

1. Monitoring costs which are the agency cost incurred and borne by the principal for overseeing the agent's behavior by observing, measuring and controlling the behavior of the agent, such as the operation cost arrangement.

2. Costs of bonding a set of contracts or bonding costs which are incurred by the principal with the aim of establishing a contract which ensures that the agent adheres to the mechanism and acts in the interest of the principals.

3. Residual losses are the costs that arise from the fact that sometimes the agent behaves in contrast to the principal's interest.

\subsection{Ownership structure}

Ownership structure, as one of the dimensions of corporate governance, is believed to influence the company performance through its influence on the principal-agent relationships. Oman (2001) explained that the successful implementation of good corporate governance cannot be separated from the ownership structure of the company. Therefore, to implement good corporate governance, the ownership structure is considered crucial in addressing the agency problem, because good ownership structure makes the manager have appropriate and sufficient authority to carry out their duties in the company management.

The ownership structure is defined as the distribution of shares with regard to votes and capital and also by the identity of the shareholders. The term ownership structure has two widely applied dimensions, which are ownership concentration and owner identity. Ownership concentration provides quantitative information on the capital right of the largest shareholders in the company, while owner identity information provides qualitative information on the character of the controlling shareholders of the company. The effect of ownership structure on corporate performance is a part of the management and strategy literature. The existence of an ownership structure effect is based on the argument that different owners may have different strategic goals, such as the strategy of valuation, profitability, growth and risk, in accomplishing the company's goals. In addition, different types of ownership structure make the owner have different controlling preference, which influences the operation and performance of the company.

There are two types of ownership structures: 1) dispersed ownership and 2) concentrated ownership. A company with dispersed ownership tends to give greater compensation to the management team as compared to the company with concentrated ownership. The impact of ownership concentration is shown to be related with higher shareholder value and is also dependent on ownership identity (Thomsen \& Pedersen, 2000). This is because concentrated ownership creates two groups of shareholders that are classified into the majority shareholders who act as the controlling interest and the minority shareholders. In addition to the ownership structure's characteristics, there are also some types of ownership structure, which are foreign, government, institutional, managerial, family and public ownership. In this research, the researcher used the institutional and managerial ownerships.

\subsection{Previous research}

The impact of ownership structure on company performance is a significant topic. It has been studied over a period of time by researchers, but there are still some limitations, resulting in inconsistent research findings. The following are excerpts from some previous studies regarding this topic: studies by Charfeddine and Elmarzougui (2010) using ordinary least square (OLS) and two-stage least squares (2SLS) showed that institutional ownership, firm size, debt ratio, ROA, BETA and DPR have a negative impact on firm performance, while fraction of sales revenue has a significant positive impact on firm performance. Also, Vincent and Peter (2011) utilized Pearson's Correlation and Logistic Regression and found that ownership concentration and government ownership have a significant negative relationship with firm performance, foreign ownership, diffuse ownership and corporation ownership, while managerial ownership has a significant positive relationship with 
firm performance. Then, by using panel data analysis, Alipour and Amjadi (2011) revealed that the greatest shareholder has a negative and significant effect; five biggest shareholders have a positive and significant effect; institutional ownership; individual ownership and managerial ownership has a negative and significant effect on the company performance.

Using regression analysis, Amran and Ayoib (2013) showed that managerial and family ownership relates significantly to ROA and ROE; and firm performance decreases when the managers' share ownership increases. Furthermore, by employing the common effect robust model, Wahla et al. (2012) concluded that managerial ownership has a significant negative relationship with firm performance; concentrated ownership showed insignificant relationship with firm performance; leverage showed a significant negative relationship with firm performance; and insignificant relationship between asset turnover and firm performance. A similar study by Wiranata and Yaterina (2013) showed that foreign ownership and leverage have a positive and significant effect on profitability; family ownership has a negative and significant effect on profitability; government, managerial, institutional ownership, and firm size have no effect on profitability.

From the above empirical findings, it can be concluded that there are so many heterogeneous research findings regarding this topic. There are still limitations, for instance, the time span, which led to the inconsistent results. To prove whether there is an influence of ownership structure on the company performance, the authors intend to carry out further research, since the results of this topic are still inconsistent. The differences between the authors research and previous studies are that, although the authors used institutional and managerial ownership as independent variables, for the dependent variables, the authors used Economic Value Added (EVA) and Tobin's Q. In addition, the authors also used the company size as a control variable. The research objects are the companies of the property and the real estate sector listed on the Indonesia Stock Exchange (IDX) during the years 2010-2015.

\section{RESEARCH METHOD}

\section{Population and sample}

The population used in this research consists of companies in the property and real estate sector listed on the Indonesia Stock Exchange (IDX). The sample was selected by using the purposive sampling technique, which is non-probability sampling, to select them by specifying the types of objects that can provide the desired information "either because they are the only ones who have it or conform to some criteria set by the researcher" (Sekaran \& Bougie, 2009, p. 276). The total number of listed companies of the property and real estate sector of the Indonesia Stock Exchange (IDX) is 55 companies and, finally, 40 companies were selected during the period 2010-2015 with 240 observations.

\section{Research variable and operational definition}

The research variables can be divided into three types, which are independent, dependent and control variables.

\section{Independent variable}

In this research, the independent variable is the ownership structure of companies of the property and real estate sector listed on the Indonesia Stock Exchange (IDX), which is divided as follows:

\section{Institutional ownership}

Institutional ownership refers to the proportion of the company's shares held by the organizations or institutions, which can be measured by the percentage of common shares owned by the external organizations or institutions. The organizations or institutions include financial organizations such as the bank, insurance companies, investment corporations, non-financial organization or other types of organizations. The shares percentage can be calculated using the following formula:

$I N S T=\frac{\text { Number of Shares held by the Institutions }}{\text { Total of Company's Shares }}$. 


\section{Managerial ownership}

Managerial ownership is the proportion of the company's shares held by the management, which can be measured by the percentage of common shares owned by the management who is actively involved in the company's decision-making. The following formula is used to calculate the percentage of managerial shares:

MANAG $=\frac{\text { Number of Shares held by the Insiders }}{\text { Total of Company's Shares }}$.

\section{Dependent variable}

In this research, the company performance was measured by utilizing Economic Value Added (EVA) and Tobin's Q (Q ratio).

\section{Economic Value Added (EVA)}

EVA refers to a financial management system for measuring the economic profit of a company, which states that prosperity can only be achieved if the company is able to fulfill all the operating costs and cost of capital (Tunggal, 2008, p. 1). By utilizing EVA, the management can compute both cost of debt and cost of equity as the cost of capital, which will result in more accurate results.

Mathematically, the basic formula for EVA can be written as follows (Brigham \& Ehrhardt, 2005, p. 49):

$$
\begin{gathered}
E V A=N O P A T-\left[\begin{array}{l}
\text { After tax cost } \\
\text { of capital used } \\
\text { to support operations }
\end{array}\right] ; \\
E V A=\text { Operating_Capital } \cdot(\text { ROIC }- \text { WACC }) ; \\
E V A=\frac{\text { Operating Capital } \cdot \text { NOPAT }}{\text { Average Capital }-W A C C},
\end{gathered}
$$

where

NOPAT = Net Operating Profit After Tax,

ROIC $=$ Return on Invested Capital,

WACC $=$ Weighted Average Cost of Capital.

\section{Tobin's Q (Q ratio)}

Tobin's $\mathrm{Q}$ is the ratio of the market value of firm assets (as measured by the market value of its outstanding stock and debt) to the firm's total assets. It is used to measure the company's value. The measurement of Tobin's Q for non-financial companies (Chung \& Pruitt, 1994, pp. 70-74) is as follows:

$$
\text { Tobin's } \mathrm{Q}=\frac{M V S+D}{T A}
$$

To be more specific, the formula for measuring Tobin's Q can be rewritten as:

$$
\begin{aligned}
& \text { Tobin's } Q=\frac{\text { Stock Price } \cdot \text { Out standing Shares }}{\text { Total Asset Value }}+ \\
& +C L-C A+L T L, \\
& \text { where } C L=\text { Current Liability, } \\
& C A=\text { Current Asset, } \\
& \text { LTL }=\text { Long }- \text { Term Liability. }
\end{aligned}
$$

\section{Control variables}

\section{Firm size}

One of the benchmarks that indicates the measurement of the company size is the company's total assets. Companies which possess large total assets show that they have reached the maturity stage. It reflects that the companies are relatively stable and are able to generate better profits as compared to companies that possess a small amount of total assets (Basuki, 2006). The formula for calculating the company's size is:

\section{LnSize $=$ Logarithm Natural of Total Asset.}

\section{Debt ratio}

Financial leverage is an indicator for measuring company performance; there are positive impacts on leverage and performance, because the large financial leverage supports the debt holders to control the agent and reduce agency costs (Modigliani \& Miller, 1958; Jensen, 1989; Kim \& Sorensen, 1986). However, Myers (1977) argued that good companies tend to avoid high leverage and use more internal sources of fund. The debt ratio of the company is calculated as follows:

$$
D E R=\frac{\text { Long_term Debt }}{\text { Total Equity }} .
$$

\section{Systematic risk, $\beta$}

Beta measures the volatility of return of a security or the systematic risk of the corporation and 
it indexes the cost of capital. Therefore, the relevant risk of an individual stock, which is called its beta coefficient, is defined under the CAPM as the amount of risk that the stock contributes to the market portfolio. Beta are generally estimated from the stock's characteristic line by running a linear regression between past returns on the stock in question and past returns on some market index (Brigham \& Ehrhardt, 2005)

\section{Model specification}

In order to analyze the influence of ownership structure on EVA and Tobin's Q, this research utilized the following multiple regression analysis model:

\section{Model I:}

$E V A_{i t}=\alpha+\beta \cdot I N S T_{i, t}+\beta \cdot M_{A N A G_{i, t}}+\beta \cdot \operatorname{SIZE}_{i, t}+$ $+\beta \cdot D E R_{i, t}+\beta \cdot B E T A_{i, t}+\varepsilon_{i, t}$.

\section{Model II:}

Tobin's $Q_{i t}=\alpha+\beta \cdot I N S T_{i, t}+\beta \cdot M_{A N A G_{i, t}}+$ $+\beta \cdot \operatorname{SIZE}_{i, t}+\beta \cdot D E R_{i, t}+\beta \cdot$ BETA $_{i, t}+\varepsilon_{i}$,

where:

$E V A_{i, t}$ - Economic Value Added for firm $i$, period $t$ for model I; Tobin's $\mathrm{Q}_{i t}$ - value of Tobin's $\mathrm{Q}$ for firm $i$, period $t$ for model II; $\alpha$ - constanta; $\beta$ - regression coefficient; $I N S T_{i, t}-$ percentage of shares owned by institutional investors for firm $i$, period $t ; M A N A G_{i, t}$ - percentage of shares owned by managerials for firm $i$, period $t$; $S I Z E_{i, t}$ - logarithms company size for firm $i$, period $t ; D E R_{i, t}$ - total long-term debt to total equity for firm $i$, period $t$; BETA $A_{i, t}$ - systematic risk for firm $i$, period $t ; \varepsilon_{i, t}$ - error coefficient.

The Fixed-Effect Model (FEM) is the model used in estimating the panel data by overseeing the intercept differently. In the cross section and time series data, the intercept is constant for each individual $i$ and time $t$. But in this FEM, the intercept in the model is able to change for each individual $i$ and time $t$. The definition of FEM is based on the intercept differences between the company with the same intercept between the time. This model also assumes that the slope is the same for the company and time. Whereas, in the RandomEffect Model (REM), the characteristic difference of the individual and time is accommodated by the error in the model. The error component in this model emanated from the error of the individual and error of time. Hence, the random error in this model needs to be incorporated into the individual error component, the time error component, and the combination error.

\section{RESEARCH FINDINGS}

\subsection{Descriptive statistics analysis}

Descriptive statistics analysis aims to provide the systematic, factual and accurate description regarding the data statistics such as number of samples, minimum value, maximum value, average value, mode, median, standard deviation of the data and others. The descriptive statistics helps in simplifying the data into the information which is more obvious and understandable. The following table is the descriptive statistics analysis of the research data, which provides the general overview of the number of data, minimum value, maximum value, mean and standard deviation of the data.

Based on the descriptive statistics table given below institutional ownership is an independent variable, which is measured by the share proportion held by the external organizations or institutions. It shows that the average value is $58.08 \%$, minimum value is $0 \%$, maximum value is $92.88 \%$, and the standard deviation is $24.60 \%$. The second independent variable is the managerial ownership structure. It shows the percentage of common shares owned by the management who is actively involved in the company's decision-making. The mean of managerial ownership based on 240 observations is $2.58 \%$, while the minimum and maximum percentage of managerial ownership is 0 and $11.22 \%$, and the standard deviation is $3.61 \%$.

Size as the control variable is measured by the logarithm natural (Ln) of the company's total asset. The companies with large total assets have reached the maturity stage. It shows that the company is relatively stable and able to generate better profits as compared to the companies that possess a small amount of total assets. Based on the table below it can be seen that the size variable has a mean of 28.192 , the lowest value being 
25.639 and the highest value being 30.245 with a standard deviation of 1.267 . Debt to total equity (DER) and BETA variables have mean, as well as minimum and maximum values of 0.475 and 1.270, 0.300 and 1.100, and 0.700 and 1.500, respectively.

EVA as the company's financial performance measurement for model I, recorded an average of Rp 55.374,957,315. The minimum and maximum

EVA values of the 240 total data $(N)$ are, respectively, Rp 673.902,905,942 and Rp 944.176,688,339, while the standard deviation is $\mathrm{Rp} 280.005,548$. The second dependent variable is the company's financial performance for model II called Tobin's Q. From the table given below the average ratio of Tobin's $\mathrm{Q}$ is 0.901 , the lowest ratio is -0.078 , the highest ratio is 3.546 , while the standard deviation is 0.706 .

Table 1. Descriptive statistics

\begin{tabular}{|c|c|c|c|c|c|}
\hline Variable & $\mathbf{N}$ & Minimum & Maximum & Mean & $\begin{array}{c}\text { Std. } \\
\text { deviation }\end{array}$ \\
\hline INST & 240 & .000 & 92.880 & 58.080 & 24.600 \\
\hline MANAG & 240 & $.000 w$ & 11.220 & 2.580 & 3.610 \\
\hline SIZE & 240 & 25.639 & 30.245 & 28.192 & 1.267 \\
\hline DER & 240 & 0.300 & 0.700 & 0.475 & 0.670 \\
\hline BETA & 240 & 1.100 & 1.500 & 1.270 & 1.030 \\
\hline EVA & 240 & -673.903 & 944.177 & 55.375 & 280.006 \\
\hline Tobin's Q & 240 & -0.078 & 3.546 & 0.901 & 0.706 \\
\hline
\end{tabular}

\subsection{Results of regression analysis}

This research has two multiple regression models, which are model I with EVA as the dependent variable $\left(Y_{i t}\right)$ and model II with Tobin's $\mathrm{Q}$ as the dependent variable $\left(Y_{i t}\right)$. In this study, the panel data regression utilized the Generalized Least Square (GLS) method. The GLS method, which is used in data analysis, utilizes two types of model, which are the Fixed-Effect Model (FEM) and RandomEffect Model (REM). In order to choose the best model in explaining the influence of the independent variable on the dependent variable between FEM and REM, Hausmann's test was used.

The following section shows the output of regression analysis for model I, in which EVA is the de- pendent variable, and for model II, where Tobin's Q is the dependent variable, which is not presented in this paper, because the results did not fulfill the statistical purposes. In Table 2 regarding the FEM and REM models estimation result for model I, it can be observed that FEM is a better estimator as compared to REM, where the two independent (institutional and managerial) and control variables (the company size and debt ratio) have significant impact on EVA. It can be seen that FEM also has larger adjusted $\mathrm{R}^{2}$ than REM, which is 0.5865 $(0.5865>0.0917)$. To determine the best model between FEM and REM in explaining their dependent variable, Hausmann's test was utilized. By observing the Hausmann's test result, it can be seen that the probability value (p-value) is 0.000 , which is less than $\alpha$ value (0.05). Thus, the appropriate model in explaining the influence of independent variable on the dependent variable is FEM. Table 2 also shows the t-test output with a significant level of $\alpha=5 \%$, so further explanation for each independent and control variable is as follows.

The institutional ownership structure has a probability value of 0.0001 . It is less than the significance level of 0.01 , so, it indicates that the institutional ownership structure individually has a significant influence on EVA as the company performance. Institutional ownership structure has a negative coefficient that indicates a negative influence on the company. Thus, institutional ownership has a negative relationship with the company performance. From the probability value section, the managerial ownership structure recorded a probability value of 0.0501 . This is lower than the significance level of 0.10 , so, it indicates that the managerial ownership structure individually has a partially significant negative influence on EVA as performance of companies of property and real estate sector listed on the Indonesia Stock Exchange. Managerial ownership is the proportion of shares owned by the management. It means that the manager also acts as the owner and has the right to take decision related to the company. According to the agency theory, if the manager has interests different from that of the owners of the company, it will trigger conflict, which is known as agency conflict. This conflict can make the company not have good performance. 
Table 2. Regression analysis results

\begin{tabular}{|c|c|c|}
\hline Variable & Fixed-Effect Model (FEM) & Random Effect-Model (REM) \\
\hline \multirow{2}{*}{ C } & $-6.2371^{* * *}$ & $-2.0711^{*}$ \\
\hline & $(0.0000)$ & $(0.0567)$ \\
\hline \multirow{2}{*}{ INST } & $-4.7695^{* * *}$ & -1.0137 \\
\hline & $(0.0001)$ & $(0.3158)$ \\
\hline \multirow{2}{*}{ MANAG } & $-1.7310^{*}$ & -1.3048 \\
\hline & $(0.0501)$ & $(0.2749)$ \\
\hline \multirow{2}{*}{ LnSIZE } & $6.3230^{* * *}$ & $2.3734 * *$ \\
\hline & $(0.0000)$ & $(0.0317)$ \\
\hline \multirow{2}{*}{$D E R$} & $-3.6540^{* * *}$ & $-2.2570^{* *}$ \\
\hline & $(0.0039)$ & $(0.0420)$ \\
\hline \multirow{2}{*}{ BETA } & -1.4412 & -1.4150 \\
\hline & $(0.2190)$ & $(0.3107)$ \\
\hline Adjusted R2 & 0.5865 & 0.0917 \\
\hline F-statistic & $5.7097^{* * *}$ & $2.4993^{* *}$ \\
\hline Durbin-Watson stat & 2.3271 & - \\
\hline Hausmann's test & $48.2820^{* * *}$ & - \\
\hline
\end{tabular}

Note: significant at: ${ }^{\star} \mathrm{p}<0.10 ;{ }^{* *} \mathrm{p}<0.05 ;{ }^{* *} \mathrm{p}<0.01$.

The result of negative relationship between managerial ownership and the company performance is consistent with the researches of Alipour and Amjadi (2011) and Whala et al. (2012). On the other hand, the finding is in contradiction with the research by Vincent and Peter (2011) in which managerial ownerships have a significant positive relationship with firm performance. Two of the control variables, which are the SIZE of the company and debt ratio, have a significant impact on EVA as performance of companies of property and real estate sector listed on the Indonesia Stock Exchange. This finding is consistent with the previous research by Sofyaningsih (2011), Putra (2013), and Charfeddine and Elmarzougui (2010). But the research finding of Wiranata and Yaterina (2013) is different. They mentioned that firm size has no influence on profitability.

\section{CONCLUSION AND RECOMMENDATIONS}

The results of testing showed that institutional and managerial ownership have a negative significant effect on the company performance. The company's size has a positive significant influence, and debt ratio has a negative significant influence on performance of companies of property and the real estate sector. Based on the analysis and results of this research, hence, the recommendations for the companies of property and real estate sector, they can reduce the proportion of shares held by the institutions and increase the proportion of shares owned by the company's manager to further observe if it will have any impact on the company's performance. It is also suggested for related institutions in this case, the property and real estate sector that they must pay close attention to the profile of the owner who is going to be the company's shareholder, whether it is the institution's profile or manager's profile, so that they can harmonize their interest. The company can create more value by improving its operation efficiency, in this case, by improving the profit without adding more capital, by increasing investment in the project with high return, and withdrawing from unrewarding business.

From the statistical results, the institutional and managerial ownership have a significant effect on corporate performance. Hence it is essential for both companies and the shareholders to consider the relationship between the ownership structure and the company performance before the management choose the action and the shareholders make the investment decision in the property and real estate sector. The investors can consider investing in companies with the positive value of EVA. It is suggested for upcoming research to add another sector to increase the amount of research sample, and extend the 
period of observation, which hopefully will provide better and more consistent result. In addition, other types of ownership structure can also be considered as the independent variables (such as foreign and domestic ownership), and other types of company performance (such as the financial ratios) can be used as the dependent variables with the expectation that it can provide better results.

\section{REFERENCES}

1. Alipour, A., \& Amjadi, H. (2011). The Effect of owership Structure on Corporate Performance of Listed Companies in Tehran Stock Exchange: An Emperical Evidence of Iran. International Journal of Business and Social Science, 2(13), 49-55. Retrieved from http://ijbssnet.com/journals/Vol._2_No._13_ Special_Issue_July_2011/6.pdf

2. Amran, N. A., \& Ayoib, Ch. A. (2013). Effects of Ownership Structure on Malaysian Companies Performance. Asian Journal of Accounting and Governance, 4, 51-60. Retrieved from http://journalarticle.ukm. my/7021/1/vol4ch5.pdf

3. Brigham, E. F., \& Ehrhardt, M. C. E. (2002). Financial Management: Theory and Practice (10th ed.). Ohio: South Western.

4. Chaganti, R., \& Damanpour, F. (2006). Institutional ownership, capital structure, and firm performance. Strategic Management Journal, 12(7), 479562. http://dx.doi.org/10.1002/ smj.4250120702

5. Charfeddine, L., \& Elmarzougui, A. (2010). Institutional Ownership and Firm Performance: Evidence from France. The IUP Journal of Behavioral Finance, VII(4), 35-48.

6. Chung, K. H., \& Pruitt, S. (1994). A Simple approximation of Tobin's Q. Financial Management, 23, 70-74.

7. Craswell, A. T., Taylor, S. L., \& Saywell, R. A. (1997). Ownership structure and corporate performance: Australian evidence. Pacific-Basin Finance Journal, 5(3), 301-323. https://doi.org/10.1016/ S0927-538X(96)00028-5

8. Demsetz, H., \& Villalonga, B. (2001). Ownership structure and corporate performance. Journal of Corporate Finance, 7(3), 209-233. https://doi.org/10.1016/S09291199(01)00020-7
9. Donaldson, L., \& Davis, J. (1991). Stewardship theory or Agency theory: CEO governance and shareholder returns. Australian Journal of Management, 16, 49-64.

10. Eisenhardt, K. M. (1989). Agency Theory: An Assessment and Review. Academy of Management Review, 14(1), 57-74.

11. Hanki, C., \& Suk, D. Y. (1998). The effect of ownership structure on firm performance: Additional evidence. Review of Financial Economics, 7(2), 143-155.

12. Jensen, M. C. (1989). Agency Costs of Free Cash Flow, Corporate Finance, and Takeovers. The American Economic Review, 76(2), 323. Retrieved from http:// www.jstor.org/stable/1818789

13. Jensen, M., Meckling, W. (1976). Theory of the Firm: Managerial Behavior, Agency Cost, and Ownership Structure. Journal of Financial Economics, 3(4), 305360. https://doi.org/10.1016/0304405X(76)90026-X

14. Kapopoulos, P., \& Lazaretou, $\mathrm{S}$. (2007). Corporate ownership structure and firm performance: evidence from Greek firms. Corporate Governance An International Review, 15(2), 144-158. https://doi.org/10.1111/ j.1467-8683.2007.00551.x

15. Kim, W. S., \& Sorensen, E. H. (1986). Evidence on the Impact on the Agency Cost of Debt on Corporate Debt Policy. The Journal of Financial and Quantitative Analysis, 21(2), 131.

16. Kirkpatrick, G. T. (2006). The OECD Principles as a Reference Point for Good Corporate Governance. Presentation. Hongkong. Retrieved from http:// www.oecd.org/daf/ ca/ corporate governanceprinciples/37178663. pdf (acessed on 6 January 2015).
17. Lanouar, C., \& Elmarzougui, A. (2010). Institutional Ownership and Firm performance: Evidence from France. The IUO Journal of Behavioral Finance, VII(4), 35-46. Retrieved from https://papers.ssrn. com/sol3/papers.cfm?abstract_ id $=1751860$

18. Lauterback, B., \& Vaninsky, A. (1999). Ownership structure and firm performance: Evidence from Israel. Journal of Management and Governance, 3(2), 189-201.

19. Lemmon, M. L., \& Lins, K. V. (2003). Ownership structure, corporate governance, and firm value: Evidence from the East Asian Financial Crisis. The Journal of Finance, 58(4), 1445-1465.

20. Leng, A. Ch. A. (2004). The impact of corporate governance practices on firms' financial performance: evidence from Malaysian companies. Asian Economic Bulletin, 21(3), 308-318. Retrieved from http://www.jstor. org/stable/25773828

21. Lichtenberg, F. R., \& Pushner, G. M. (1994). Ownership structure and corporate performance in Japan. Japan and the World Economy, 6(3), 239-261.

22. Modigliani, F., \& Miller, M. (1958). The cost of capital, corporate finance, and the theory of investment. American Economic Review, 48(3), 261-297. Retrieved from http://www.jstor.org/stable/1809766

23. Monks, R. A. G., \& Minow, N (2001). Corporate Governance (2nd ed.). United Kingdom: Blackwell Publishing Ltd.

24. Mulili, B. M. (2010). Corporate Governance Practices in Developing Countries: The Case for Kenya. Journal Article, 2(1), 14-27. https://doi.org/10.5430/ijba. v2n1p14 
25. Oman, C. P. (2001). Corporate Governance and National Development (OECD Development Centre Technical Paper, No 180).

26. Pearce II, John, A., \& Richard, B. R. (2011). Strategic Management: Formulation, Implementation, and Control (12th ed.). New York: McGrawHill Companies, Inc.

27. Schaar, R. M. A. Van Der. (2015). Analisis Pasar Properti Indonesia: Overview \& Kepemilikan Asing. Retrieved from https://www.indonesia-investments.com (accessed on 18 May 2015).

28. Schreiben, R. (2013). Prospek Indonesia menjadi tujuan utama investasi properti di dunia (Indonesia become a major prospects for property investment destination in the world). Architekt Und Oekonom. Retrieved from http://www. reiyslbswordpress.com (accessed on 6 January 2015)
29. Sekaran, U., \& Roger, B. (2009). Research Method for Businesss: A Skill Building Approach (5th ed.). United Kingdom: John Wiley \& Sons Ltd.

30. SShleifer, A., \& Vishny, R. W. (1997). A survey of corporate governance. Journal of Finance, 52(2), 738 .

31. Smith, A. J. (1990). Corporate ownership structure and performance. Journal of Financial Economics, 27(1), 143-164.

32. Sofyaningsih, S. (2011). Ownership Structure, Dividend Policy, and Firm Value. Jurnal Keuangan dan Perbankan, 3(1), 68-87.

33. Thomsen, S., \& Pedersen, T. (2000). Ownership structure and economic performance in the largest European companies. Strategic Management Journal, 21(6), 689-705. http://dx.doi. org/10.1002/(SICI)10970266(200006)21:6<689::AIDSMJ115>3.0.CO;2-Y
34. Tunggal, W. A. (2001). Memahami Konsep Economic Value Added (EVA) dan Value Based Management (VBM). Jakarta: Harvarindo.

35. Vincent, O. O., \& Peter, O. K. (2011). Effects of selected Corporate Governance Characteristics on Firm Performance: Empirical Evidence from Kenya. Internatiomal Journal of Economics and Financial Issues, 1(3), 99-122.

36. Wahla, K. R., Ali Shah, S. Z., \& Hussain, Z. (2012). Impact of Ownership Structure on Firm Performance Evidence from Non-Financial Listed Companies at Karachi Stock Exchange, International Research. Journal of Finance and Economics, 84.

37. Wiranata, Y. A., \& Yaterina, W. N. (2013). Pengaruh Struktur Kepemilikan Terhadap Profitabilitas Perusahaan Manufaktur di Indonesia. Research Journal of Finance and Accounting, 15(1), 15-26. http://dx.doi. org/10.9744/jak.15.1.15-26 